\title{
INDICATORS FOR ASSESSING THE REGULATORY POLICY OF THE DEVELOPMENT OF THE NATIONAL ECONOMY
}

\section{Hanna Razumova ${ }^{1}$ Olena Oskoma ${ }^{2}$}

\author{
DOI: https://doi.org/10.30525/978-9934-588-11-2_69
}

An important role in the economic system of each country is played by the state. This is associated with the fact that among the main functions of the state, there is the function of regulating the economic processes of society as a whole and the economic activities of economic entities in particular. The key to positive changes in the development of Ukraine's national economy is an effective mechanism for regulating economic development that is able to respond to a wide range of problems and challenges in a timely manner. In this context, the formation of an effective regulatory policy for the development of the national economy should be based, first of all, on the assessment of the existing level of development. This assessment is an essential and essential component of strategic planning, regulation, and management of national economic development.

The establishment of a balanced regulatory mechanism for the development of the national economy should be based on a comprehensive assessment, which is proposed to be carried out on the basis of a system of regulatory policy assessment indicators and its results in the form of two subsystems: indicators for assessing the development of the national economy (regulatory policy results) [1] and indicators for assessing changes in regulatory policy [2].

Before assessing, it is important to pay attention to the formation of a system of indicators, which will be used for the assessment, and to identify performance indicators.

The subsystem of indicators of the assessment of the development of the national economy is based on the indicators used by the World Bank experts in assessing sustainable economic development - Sustainable Economic Development Assessment (SEDA) - Figure 1.

SEDA makes it possible to diagnose social and economic conditions of development based on indicators, which are grouped into three categories: economy, investments, and sustainable development [3].

The main goal of SEDA is to help governments to identify policy priorities and develop a national economy's development strategy aimed at improving the longterm social and economic well-being of citizens based on comparative analysis with reference countries [3]. In our view, the indicators used in the SEDA calculation most fully characterize development in comparison with other countries, and therefore, are suitable for individual assessment of the development of a particular country.

\footnotetext{
${ }_{2}^{1}$ Prydniprovska State Academy of Civil Engineering and Architecture, Ukraine

${ }^{2}$ Prydniprovska State Academy of Civil Engineering and Architecture, Ukraine
} 


\begin{tabular}{|c|c|c|}
\hline Economy & $\begin{array}{c}\text { Sustainable } \\
\text { development }\end{array}$ & Investments \\
\hline$\nabla$ & $\nabla$ & $\nabla$ \\
\hline Income & Equality & Health \\
\hline Economic stability & Civil society & Infrastructure \\
\hline \multirow[b]{2}{*}{ Employment } & Governance & \multirow[b]{2}{*}{ Education } \\
\hline & Environment & \\
\hline
\end{tabular}

\section{Figure 1. The system of indicators for assessing the development of the national economy}

Source: compiled based on [3]

As indicated in Figure 2, it is proposed to include to the indicators characterizing the regulatory policy the following:

- components of the Doing Business ranking (each of these components in one way or another characterizes the regulation of the national economy): starting a business, dealing with construction permits, getting electricity, registering property, getting credit, protecting minority investors, paying taxes, trading across borders, enforcing contracts, resolving insolvency [4];

- two Worldwide Governance Indicators (these two indicators characterize regulatory policy in the country): regulatory quality and government effectiveness indicators [5];

- three indicators of the 5th component of business regulation of the Economic Freedom of the World rating: credit market regulations, labour market regulations, and business regulations [6].

\begin{tabular}{||c||c|c||}
\hline $\begin{array}{c}\text { Ease of doing } \\
\text { business indicators }\end{array}$ & $\begin{array}{c}\text { Regulatory quality and } \\
\text { government effectiveness } \\
\text { indicators }\end{array}$ & $\begin{array}{c}\text { Business regulation } \\
\text { indicators }\end{array}$ \\
\hline \hline \begin{tabular}{c|c|} 
Based on \\
components of \\
Doing Business
\end{tabular} & $\begin{array}{c}\text { Based on relevant } \\
\text { indicators of } \\
\text { World Governance } \\
\text { Indicators }\end{array}$ & $\begin{array}{c}\text { Based on indicators of the } \\
\text { Business Regulation } \\
\text { component of } \\
\text { Economic Freedom of the } \\
\text { World }\end{array}$ \\
\hline
\end{tabular}

Figure 2. The system of regulatory policy assessment indicators

Source: compiled based on [4-6] 
The aforementioned components of the system of indicators (its subsystems) can be used as separate structural elements, on the basis of which comprehensive information about a particular process can be obtained:

- the subsystem of indicators for assessing the development of the national economy by sectors, based on which indices of change, which are further reduced into aggregate indices, are determined - serves as a basis for a comprehensive understanding of changes occurring in different areas, as well as highlighting problem areas;

- the subsystem of regulatory policy assessment indicators, based on which indices of change, which are further reduced to generalized indices, are determined - serves as a basis for obtaining information on how much regulation has improved or deteriorated for each of the areas of development.

\section{References:}

1. Razumova, H. (2019). Methodical approach to polydiagnostic evaluation of the national economy development. The potential of modern science: collective monograph. Editor: Babych M.M. London, United Kingdom: Sciemcee Publishing, Vol. 2. pp. 173-182.

2. Razumova, H. V. (2019). Pidkhid do otsinky rehuliatornoi polityky ta yii vplyvu na rozvytok ekonomiky [Approach to regulatory policy evaluation and its effects on economic development]. Ekonomichnyi prostir: Zbirnyk naukovykh prats [Economic space: Collection of scientific works]. Dnipro: PDABA, № 142, pp. 78-87. doi: 10.30838/P.ES.2224.260219.78.380

3. Striking a Balance Between Well-Being and Growth: The 2018 Sustainable Economic Development Assessment. Retrieved from: https://www.bcg.com/publications/2018/seda-strikingbalance-between-well-being-growth.aspx (accessed 15.06.2019).

4. Ease of Doing Business Score and Ease of Doing Business Ranking. Retrieved from: http://www.doingbusiness.org/content/dam/doingBusiness/media/Annual-Reports/English/DB19-

Chapters/DB19-Score-and-DBRankings.pdf (accessed 15.06.2019).

5. The Worldwide Governance Indicators (WGI) project. Retrieved from: http://info.worldbank.org/governance/wgi/\#home (accessed 15.06.2019).

6. Economic Freedom of the World: 2008 Annual Report. Retrieved from: https://www.fraserinstitute.org/sites/default/files/EconomicFreedomoftheWorld2008.pdf (accessed 15.06.2019). 